\title{
Eosinophilic granulomatosis polyangiitis associated with acute acalculous cholecystitis
}

\author{
Eriko Takeda, ${ }^{1,2}$ Kiyoshi Shikino (1) ${ }^{1}$
}

${ }^{1}$ Generai Medicine, Chiba University Hospital, Chiba, Japan ${ }^{2}$ General Medicine, Sanmu Medical Center, Sanmu, Chiba, Japan

\section{Correspondence to}

Dr Kiyoshi Shikino; kshikino@gmail.com

Accepted 30 June 2021

\section{DESCRIPTION}

A 53-year-old man presented with a 2-week history of progressive skin rash, numbness, arthralgia and myalgia, as well as a 9-month history of cough and wheezing. He was diagnosed with new-onset asthma and underwent inhaled steroid therapy; however, this treatment was ineffective for cough and wheezing. His medical history also included intractable chronic sinusitis, and he denied abdominal pain. Physical examination revealed erythema, purpura and bullae on the extremities. Laboratory test results showed a white blood cell count of 24 $700 \mu / \mathrm{L}$ with hypereosinophilia $(13585 \mu / \mathrm{L})$, lactate dehydrogenase of $300 \mathrm{U} / \mathrm{L}, \gamma$-glutamyl transpeptidase of $207 \mathrm{U} / \mathrm{L}$, alkaline phosphatase of $596 \mathrm{U} / \mathrm{L}$, $\mathrm{C}$ reactive protein of $6.5 \mathrm{mg} / \mathrm{dL}$ and an increased myeroperoxidase antineutrophil cytoplasmic antibody (MPO-ANCA) titre. A nerve conduction study showed decreased amplitude with axonal neuropathy. Abdominal ultrasonography revealed gallbladder wall thickening without obvious gallstones (figure 1). Fluorodeoxyglucose positron emission tomography (FDG-PET) revealed abnormal tracer accumulation in the gallbladder wall without any luminal uptake, typically referred to as 'the rim sign' (figure 2), which suggested acute acalculous cholecystitis (AAC). Histopathological evaluation of a skin biopsy specimen showed eosinophilic infiltration and granuloma. Based on the clinical presentation and elevated MPO-ANCA titre, the patient was diagnosed with eosinophilic granulomatosis with polyangiitis (EGPA). The patient's symptoms including those associated with AAC improved after intravenous pulse corticosteroid therapy, and no relapse occurred after the 5-year follow-up.

AAC, defined as an acute necroinflammatory disease of the gall bladder in the absence of cholelithiasis, accounts for approximately $10 \%$ of all cases of acute cholecystitis and shows

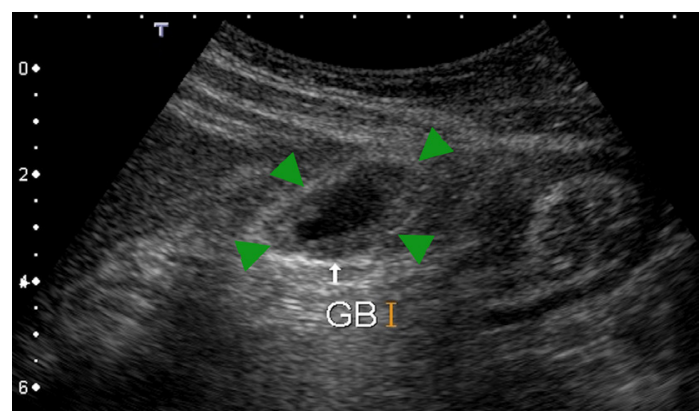

Figure 1 Abdominal ultrasonography showed thickening of the gallbladder wall (arrowheads) but no obvious gallbladder stones.

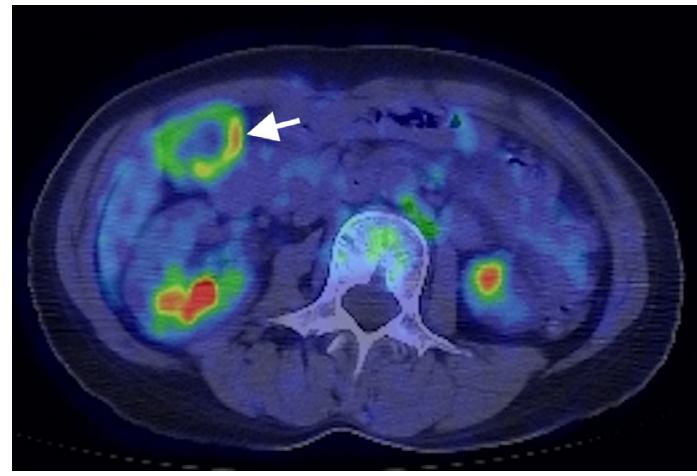

Figure 2 Fluorodeoxyglucose positron emission tomography showed abnormal accumulation in the gall bladder wall with no uptake in the lumen (the rim sign, arrow).

multifactorial pathogenesis. ${ }^{1}$ It is strongly associated with a variety of clinical conditions, the most common being diabetes mellitus, malignancies, congestive heart failure and shock. ${ }^{2}$ Systemic vasculitides, including EGPA, polyarteritis nodosa, immunoglobulin A vasculitis, cryoglobulinaemic vasculitis and giant cell arteritis may predispose individuals to AAC. ${ }^{3}$ Organ hypoperfusion is implicated as a pathogenetic contributor to AAC. ${ }^{4}$ Laboratory tests in patients with AAC show non-specific results and include elevated serum bilirubin, alkaline phosphatase and aminotransferases. ${ }^{5}$ Radiological features suggestive of AAC include

\section{Patient's perspective}

I was told that acute cholecystitis would require surgical removal, but it was good to know that it improved with medication alone.

Learning points

- Acute acalculous cholecystitis (AAC) accounts for approximately $10 \%$ of all cases of acute cholecystitis.

- Systemic vasculitides, including eosinophilic granulomatosis with polyangiitis, may predispose individuals to AAC.

- AAC associated with rheumatic or autoimmune diseases may possibly show a better response to early immunosuppressive therapy without the need for surgical intervention. 
gallbladder wall thickening, the sonographic Murphy's sign and visualisation of pericholecystic fluid. ${ }^{6}$ FDG-PET in our patient revealed increased FDG uptake in the gallbladder wall without any luminal uptake, typically referred to as the rim sign. ${ }^{7}$ AAC associated with rheumatic or autoimmune diseases may possibly show a better response to early immunosuppressive therapy without the need for surgical intervention. ${ }^{8}$

Twitter Kiyoshi Shikino@K

Contributors ET and KS managed the patient and checked the final manuscript. ET wrote the first draft. KS revised the manuscript.

Funding The authors have not declared a specific grant for this research from any funding agency in the public, commercial or not-for-profit sectors.

Competing interests None declared.

Patient consent for publication Obtained.

Provenance and peer review Not commissioned; externally peer reviewed.
ORCID iD

Kiyoshi Shikino http://orcid.org/0000-0002-3721-3443

\section{REFERENCES}

1 Huffman JL, Schenker S. Acute acalculous cholecystitis: a review. Clin Gastroenterol Hepatol 2010:8:15-22.

2 Barie PS, Eachempati SR. Acute acalculous cholecystitis. Curr Gastroenterol Rep 2003:5:302-9.

3 Hernández-Rodríguez J, Tan CD, Rodríguez ER, et al. Single-organ gallbladder vasculitis: characterization and distinction from systemic vasculitis involving the gallbladder. An analysis of 61 patients. Medicine 2014;93:405-13.

4 Hermiz SJ, Diegidio P, Garimella R, et al. Acalculous cholecystitis in burn patients: is there a role for percutaneous cholecystostomy? Clin Plast Surg 2017:44:567-71.

5 Savoca PE, Longo WE, Zucker KA, et al. The increasing prevalence of acalculous cholecystitis in outpatients. Results of a 7-year study. Ann Surg 1990;211:433.

6 Barie PS, Eachempati SR. Acute acalculous cholecystitis. Gastroenterol Clin North Am 2010:39:343-57.

7 Aparici CM, Win AZ. Acute calculous cholecystitis missed on computed tomography and ultrasound but diagnosed with Fluorodeoxyglucose-Positron emission tomography/ computed tomography. I Clin Imaging Sci 2016;6:31.

8 Otsuka Y, Inoue Y. So-Called acute acalculous cholecystitis in macrophage activation syndrome. Intern Med 2016;55:3043-6.

Copyright 2021 BMJ Publishing Group. All rights reserved. For permission to reuse any of this content visit

https://www.bmj.com/company/products-services/rights-and-licensing/permissions/

BMJ Case Report Fellows may re-use this article for personal use and teaching without any further permission.

Become a Fellow of BMJ Case Reports today and you can:

- Submit as many cases as you like

- Enjoy fast sympathetic peer review and rapid publication of accepted articles

- Access all the published articles

Re-use any of the published material for personal use and teaching without further permission

Customer Service

If you have any further queries about your subscription, please contact our customer services team on +44 (0) 2071111105 or via email at support@bmj.com.

Visit casereports.bmj.com for more articles like this and to become a Fellow 